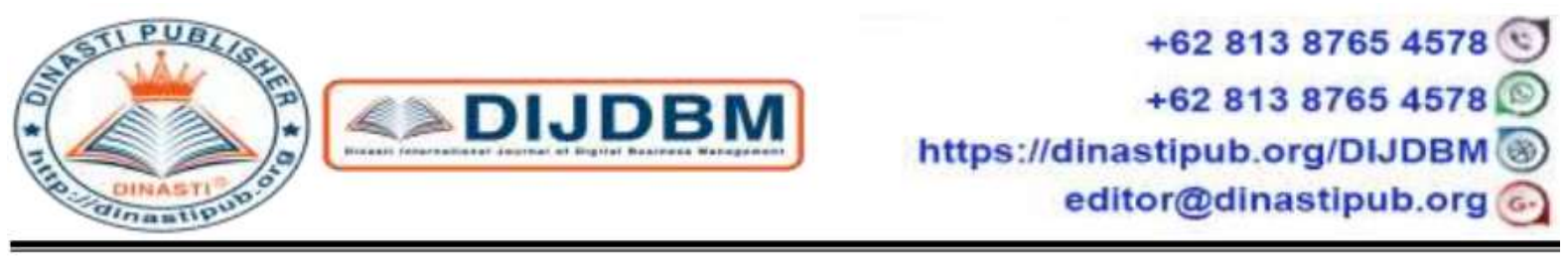

\title{
THE EFFECT OF LEADERSHIP STYLE ON THE EMPLOYEE'S PASSION AT THE BUREAU FINANCIAL AND STATE ASSETS INVENTORY THE DEPARTMENT OF RELIGION THE REPUBLIC OF INDONESIA
}

\section{Syahrian}

STIE Trisakti, Jakarta, Indonesia

\begin{tabular}{|c|l|}
\hline $\begin{array}{c}\text { ARTICLE INFORMATION } \\
\text { Received: 19 December 2019 } \\
\text { Revised: 24 December 2019 }\end{array}$ & $\begin{array}{l}\text { Abstract: The purpose of this paper is to assess the } \\
\text { ability of writers, especially in understanding the } \\
\text { knowledge and knowledge gained and apply it in } \\
\text { practice, so that later it can help the writer to convey, } \\
\text { use, apply knowledge and knowledge that has been } \\
\text { able to overcome the problem of leadership style on } \\
\text { E-mail: syahrian2014@ gmail.com } \\
\text { employee passion in Bureau of Financial and State } \\
\text { Assets Inventory Department of Religion the Republic } \\
\text { of Indonesia. This research authors compile based on } \\
\text { scientific methods, using descriptive methods, namely } \\
\text { by collecting data and providing a clear picture. This } \\
\text { data was obtained through field research, questionnaire } \\
\text { questionnaires, literature and statistical analysis to } \\
\text { prove the results that have been studied. Based on the } \\
\text { description and discussion of the influence of } \\
\text { leadership style on employee passion, the writer can } \\
\text { conclude that there is a strong influence relationship } \\
\text { between leadership style on employee passion at the } \\
\text { Financial Bureau and the State Assets Inventory of the } \\
\text { Department of Religion the Republic of Indonesia. }\end{array}$ \\
DOI:10.31933/DIJDBM &
\end{tabular}

Keywords: Leadership Style, Employee's Passion

\section{INTRODUCTION}

The issue of leadership in aspects of human life is something that is very important, especially if it is associated with the necessity of interacting with an ever-changing and evolving environment, partly because of the rapid advances that occur in the fields of science and technology. Very fast development basically contains challenges and opportunities. Therefore these developments must not only be anticipated, but must also be utilized. The leadership element is expected to have advantages compared to the implementing staff to answer the challenges and benefits and opportunities that arise.

And it is the leader who is considered capable of seeing meaningful implications and developments for life in organizations and companies. Leadership as one of the concepts of human resource management must be able to provide an experience and confidence to 
encourage all elements of all levels or levels of employees to be more advanced and motivated in generating work motivation in order to face increasingly fierce competition, where he must be able to position himself as a leader who is able to do his job well.

From the above opinion it can be stated that with the competition in increasing selfcompetition to become a leader in a government agency, it takes a high passion and is needed in every effort of employee cooperation to achieve the goals of an agency. But if an employee has low passion then it will be difficult for him to reach the position of leader in the agency. This will be different if the employee has great enthusiasm, because with great enthusiasm accompanied by hard work from the employee, it is not impossible for an employee to be able to overcome the existing difficulties.

The passion of work becomes something very important for every individual to have, if he wants to achieve the desires in his field. It is very possible for everyone to work better and this requires something in the form of good handling so that someone is able to lead in a government agency.

The experts who pursue leadership problems have done a lot of research on various aspects of leadership. Various research results have enabled modern society to have a scientific reference that theoretically provides a picture of the importance of effective leadership in life in an organizational environment, both in the field of business, statehood, politics and government or private agencies.

From the above description, it will become increasingly clear the importance of mastering the essence of leadership for all types of organizations regardless of their purpose, shape, nature, and size. An understanding of the essence of leadership is further enhanced by the experience of many people who in their life's journey have been given or had the opportunity to occupy important positions or positions in the leadership, both at the low level, middle level, and top level.

That is, the combination of theoretical and empirical understanding has provided deeper confidence among members of a variety of organizations.

How important is the leadership style in an organization, because the problem of leadership involves the relationship of the implementation of individual tasks within an organization.

Various styles of leadership run by a boss or leader will color and have a very large influence on the merits of the organization they lead. The leadership style accepted by subordinates will certainly have a positive meaning in supporting the achievement of organizational goals.

From the description above it appears that the leadership style is an interesting factor to study.

Based on the things that have been presented before, then the leadership style is an important thing to study if it is undeniable that the success of a government agency both overall and group is highly dependent on the leadership style of the superior / leader. Even if it can be accepted as a truth if it is said that the quality of leadership styles contained in an organization plays a very dominant role in terms of success.

An organization led by someone who has a good leadership style can produce its own value for that person. So that the passion of the employee can be motivated so well that makes the organization better. 
The importance of leadership style issues to the dynamics in the world of government and the dynamics of society as a whole is one of the factors that the authors find interesting to discuss. These factors are factors that are driving the various advances made by humans to improve passion at the agency or department. The existing leadership style shows that there is an influence that can be well learned through the typology of existing leadership.

To improve employee passion can be pursued by conducting an analysis that looks at the extent of the relationship between the influence of leadership style on employee passion.

This writing aims, among others:

(1) Providing ideas or ideas that are expected to be accepted and beneficial to the Department of Religion of the Republic of Indonesia, as well as being an alternative input that is useful for improving quality and quality human resources.

(2) To determine the effect of leadership style on employee passion in the Department of Religion the Republic of Indonesia.

(3) To increase knowledge about matters relating to human resources in the Department of Religion of the Republic of Indonesia.

\section{LITERATURE REVIEW}

Basically, management is an understanding that is associated with all kinds of aspects of life. Not only related to the economic and industrial fields, but also in other fields such as organizations, government, private, civil and military though.

Knowledge management is a very important thing, because management questioned the forms of business establishment and achievement of goals and objectives to be achieved by using human resources and other resources, so that the role of management is greater.

There are so many notions about management put forward by experts, to be clearer, several management definitions will be put forward according to experts, including:

Malayu S.P. Hasibuan (2001) which explains the science and art of regulating the process of utilizing human resources and other resources effectively and efficiently to achieve a goal. And T.Hani Handoko (2000) provides an explanation of management is the process of planning, organizing, directing, supervising the efforts of the members of the organization and the use of other organizational resources in order to achieve the stated organizational goals.

Human Resource Management is actually a matter of recognition of the importance of the human element as a potential resource and needs to be developed. Leadership style is one of the important aspects of discussion in human resource management, because the beginning of the creation of a leadership style that is built is with management activities that educate human resources to be more advanced and of quality so that they become a expected leader. Therefore, human resources must be managed properly to improve the effectiveness and efficiency of the organization, as one of the functions in the company known as human resource management.

Human resource management which is called personnel management by experts is defined as follows:

Eugene Mc Kenna and Nic Beech (2002) describe personnel management emphasizing the establishment, maintenance and development of systems that provide a framework for employees. Whereas Edwin B. Flippo (1984) defines personnel management as planning, organizing, directing and controlling the procurement, development, compensation, integration, maintenance and termination of employees with the aim of realizing corporate, individual and community goals. 
From the above understanding, there are important things to be explained if related to functions in human resource management which will be explained from the explanation of Edwin B. Flippo (1984) in his book explained the functions of human resource management, among others:

1. Planning, As a determination of the Personnel Program, which will help the goals that have been prepared in order to help realize the goals to be achieved.

2. Organizing, which is a series of actions that have been determined, namely the organization that is structured to achieve organizational goals based on actions or strategies that are set effectively.

3. Directing, is an activity in directing the implementation of operational functions, so that it runs according to a predetermined plan.

4. Control, namely the implementation of operational functions to run according to a predetermined plan, and has been formulated based on an analysis of the basic objectives of the organization.

5. Procurement of Workforce, which is an effort to obtain the right type and amount of personnel needed. To complete organizational goals. Things that related to this is, determining the human resources needed is starting from the recruitment, selection and placement.

6. Development (Development), is one function where after the workforce is obtained, then to a certain extent they must continue to be developed. This development has a broader scope in efforts to improve and enhance the knowledge, abilities, attitudes and personality of the workforce itself.

7. Compensation, which is a form of compensation that is adequate and appropriate for employees, for their efforts to achieve organizational goals. Compensation consists of basic salary, incentives and employee welfare.

8. Integration, an attempt to produce an appropriate reconciliation of the interests of individuals, communities, organizations and their consequences is to deal with the problems and attitudes of workers in relation to the principles and policy steps by the organization concerned.

9. Maintenance, a function where the maintenance of the physical condition of employees, both physical, passionual and mental and employee loyalty, so that employees can work with full dedication until he reaches retirement age. Of course, with the increase in welfare and health needed by these employees.

10. Separation, a function to sever work relations from the company and return these people to the community. The organization is responsible for terminating the employment relationship, in accordance with the conditions set and ensuring that those returned are in the best possible condition. Termination of employment can be in the form of achieving retirement age, the desire of employees, and dismissal by the company.

Understanding Leadership, there are many wrong concepts about leadership, but it will be very useful if there are several concepts as the initial stage. What is known that nature leadership is not understood perfectly. The most general conclusions about leadership seem to be based more on myths than on existing reality. For example, the idea that the concept of leadership is power over others at one level of the idea has some relevance. But relevance occurs if the basis of power is with people rather than themselves. The idea of leadership includes several types of reciprocal relationships between those who lead and those who are led. In the same way, the idea that some people are born leaders does not help explain the fact 
that in many cases the ability to lead seems to be achieved through practice. Raymond J. Burby (1985: 65) gives a definition that is, a leader is someone who with words or by his actions encourage people to follow him voluntarily. Meanwhile, Sondang P. Siagian (2003: 13) explained that a person would be an effective leader if he had leadership talents that were fostered and developed through the opportunity to occupy leadership positions supported by general knowledge of theory and practice concerning leadership issues. In this regard, it has been stated about leadership which is the motor or driving force of all sources and tools available to an organization. That shows the importance of the role of leadership as the main actor who drives the activities of the organization in the context of achieving its goals. Because it can also be that the success or failure of an organization to achieve the specified goals depends on the ability of members assigned to lead the organization.

Most expressed the notion of leadership is an attempt to influence others through interpersonal relationships and communication processes to achieve goals. This is one of the most common aspects where an authority will be agreed upon where leadership is some form of the process of legitimating influence. Many also agree that there are some thoughts on the task of a leader. Where the task includes leaders who act as guides and facilitators for an existing group behavior.

According to the author there are two important aspects of leadership, the first aspect is that the right to lead is often given voluntarily to the leader by several people or all group members. The second aspect is leadership which includes the motivation of group members to increase energy in achieving group goals.

Although it can give an understanding of leadership as an influence which includes ongoing transactions between leaders and followers both in a government or private agency. There are things that need to be satisfied if leadership occurs and these conditions are: the leader must show the cause of something happening, the relationship between the behavior of the leader and the relationship with passion must be observable, there must be real changes in the behavior of the employees and in the next outcome as a consequence of the leader's actions.

Consistency of leadership style, there are questions raised regarding the consistency of one's leadership style. Among other things, is the leadership style that is fixed so that it does not change even if faced with different situations or is one's leadership style flexible, which means that it is adjusted by the relevant leadership official depending on the situation at hand?

The answer to this question was not agreed upon by practitioners and scientists unanimously. As are the two things discussed about the origins of leadership. And this question also has two camps of opinion. On the one hand there is an opinion which says that one's leadership style will not change in any situation. If a person has autocratic leadership characteristics, his leadership style will be autocratic too, regardless of the organizational situation he is facing. Conversely, someone who has a democratic outlook will consistently use a democratic leadership style as well.

Adherents of leadership styles from other camps argue that one's leadership style is very situational. In practice this view means that there is no very leader.

be consistent in using one particular leadership style regardless of the situation it is facing.

According to situational theory, even the most autocratic leader will change his autocratic leadership style to another style, if a certain situation demands it. For example, an autocratic leadership style can jeopardize its position as leader and replace it with a democratic style. Conversely someone who usually uses a democratic leadership style might 
act authoritarian if the situation so desires, as in the case of imposing sanctions on disciplinary offenders and so on. The following are typologies of leadership styles that are generally known and recognized as being in the community, nation and state as well as the business environment in particular. Even though there has not been a unanimous agreement regarding the typology of leadership style that is widely known, in general there are generally 3 (three) types of leadership which the authors put forward include: (1) Democratic Type, (2) Liberal Type, (3) Autocratic Type. Each of the types above certainly has certain characteristics that distinguish between one type with another type. The things that are analyzed by various characters are based on: behavior in leading, perceptions of a leader about his role as leader, dominant leadership style, values adopted and attitudes in running an organization.

Someone who has a democratic attitude will show the following characteristics:

1. Tend to treat subordinates well and appreciate their work.

2. Flexible and open to constructive ideas, views and suggestions including from his subordinates.

3. All place the interests of the organization or agency as a whole above the interests of individuals and groups.

4. More democratic tendencies in growing and maintaining a good and conducive work climate.

5. In the decision making process the role of subordinates is very much needed.

Someone who has a liberal attitude will show the following characteristics:

1. More inclined to free employees in taking initiative in their duties / work.

2. Very free and visible without limits for leaders in giving tasks / work.

3. Delegate full authority over employees.

4. Personal interests are more important than group interests.

5. Very free in growing and maintaining a good and conducive working climate.

6. There is absolute freedom in submitting matters relating to the task / work.

Someone who has an autocratic attitude will show the following characteristics:

1. Tend to treat subordinates like machines that work continuously without respecting their human dignity and dignity.

2. Rigid in behaving and acting.

3. Authority is absolutely in the leadership.

4. More likely to force.

5. Neglecting the role of subordinates in the decision making process.

6. There is no freedom for subordinates to discuss with the leadership.

Someone said to be able to lead if they are able to know about their daily work, are able to convey the vision of an agency or organization to employees and have interpersonal skills as needed by the agency or organization.

A person's leadership style is also highly determined by his ability to recognize precisely the nature and conditions faced by him, both internal and external conditions of an agency or organization and understand the functions of the leadership style. In the description that has been explained previously about the types of leadership, it is very important that there are also essential leadership style functions, among others:

1. As a determinant of the direction to be taken by organizations / agencies in efforts to achieve goals and various targets.

2. Representatives and spokespersons for the organization / agency in relations with various parties outside the organization / agency, especially with those who are classified as stakeholders. 
3. As an effective communicator,

4. As an objective and rational integrator,

5. As a reliable mediator. If the functions mentioned above are carried out well, then a leader with the leadership style desired by his employees has a role that is certainly positive for the organization so that it certainly increases employee passion.

James J. Cribbin (1984: 151) argues that good passion is illustrated by a balance between a good work climate and satisfaction factors obtained from a comfortable and good work atmosphere. It can be said that passion is a working atmosphere found in an organization, accompanied by a sense of excitement in working better. A high passion has an important meaning marked by the enthusiasm of employees in doing the tasks / work they do everyday.

The provision of a guided guidance in the task / job will encourage subordinates to further understand the ins and outs of their work in detail. This is very important especially to avoid feeling bored or boring due to the monotonous way of working. Because the nature of work is more dealing with numbers. Because of that, a job must be attractive and able to increase work motivation. Sarwoto (1981: 135) defines motivation as the process of giving motives (driving) to work on subordinates in such a way that they are willing to work sincerely for the achievement of organizational goals efficiently. Based on the above understanding, it can be stressed that providing motivation is very necessary in a collaboration involving a number of people. This must be sought by the pipeline to influence subordinates in order to carry out their work duties optimally so that job satisfaction arises.

Shaun Tyson and Tony Jackson (1992: 29) interpret work satisfaction in a balanced way as being associated with pleasure or pleasure in job satisfaction. Where job satisfaction is reflected through the level of work discipline so as to build an appropriate orientation as a form of dedication and work discipline given by employees in a government or private agency.

Work discipline, as a matter that reflects the amount of responsibility someone has for the tasks given to him as the core of the motivation to work. As a manifestation of the goals set by an institution, both government and private. Work discipline is formed as awareness and willingness to be carried out by someone in obeying all the regulations made, the values that are built and the norms that apply in daily work activities / activities. If work discipline is continuously developed by employees, it will form a work orientation in the future. Future work orientation has the virtue gained from the form of work discipline formed and built by the employee as a form of awareness that is carried out should be accompanied by an orientation aimed at the continuity of work activities. For example, the level of work discipline that is built will increase employee passion in carrying out their activities so that the employee has an orientation to move forward in terms of career advancement, skills or expertise as well as an increase in position in the institution or organization where the employee works.

\section{RESEARCH METHODS}

To find out and measure the extent of the relationship between the influence of a leader's leadership style on employee passion, the author uses the statistical method of correlation analysis and calculation of the Hypothesis test ( $\mathrm{t}$ ) as suggested by Kusmayadi (1988: 20) with the formula:

(1) Correlation Coefficient (r)

The correlation coefficient formula is as follows: 
$r=\frac{n\left(\sum X Y\right)-\left(\sum X\right)\left(\sum Y\right)}{\sqrt{n\left(\sum X^{2}\right)-\left(\sum X\right)^{2}} \sqrt{n\left(\sum Y^{2}\right)-\left(\sum Y\right)^{2}}}$

Information :

$\mathrm{n}=$ Number of Respondents

$\mathrm{X}=$ Leadership Style

$\mathrm{Y}=$ Employee's Passion

With the following conclusions:

a. If $\mathrm{r}=1$, then the relationship between the two variables is positive and perfect.

b. If $r=0.85-0.99$, the relationship between the two variables is strong.

c. If $r=0.70-0.84$, the relationship between the two variables is quite strong

$\mathrm{d}$. If $\mathrm{r}=0.50-0.69$ then the relationship between the two variables is less strong

e. If $r=0.30-0.49$, the relationship between the two variables is low

$\mathrm{f}$. If $\mathrm{r}=0.10-0.29$, the relationship between the two variables is very low

$\mathrm{g}$. If $\mathrm{r}=0.01-0.09$ then the relationship between the two variables may be ignored

The working hypothesis as a guideline and basis for analysis in this study used the working hypothesis related to the formulation of the previous problem. The hypothesis is a temporary answer to tentative questions. With the relevant theoretical framework and available data, conclusions can be drawn from the results of the analysis. Thus the provisional hypothesis that the author can point out is that if the leadership style of a superior / leader can be well received by his subordinates, employee passion at the Bureau of Financial and State Assets Inventory of the Department of Religion the Republic of Indonesia will increase properly.

Hypothesis Test $(\mathrm{t})$ is carried out using the following formula:

$\mathrm{t}=\frac{\mathrm{r} \sqrt{\mathrm{n}-2}}{\sqrt{1-\mathrm{r}}}$

Information :

$\mathrm{t}=$ hypothesis test

$r=$ correlation coefficient

$\mathrm{n}=$ number of samples

In determining a hypothesis, it can be formulated as follows:

$\mathrm{H}_{\mathrm{o}}: \mathrm{P}=0$ (there is no relationship between the influence of leadership style with work passion).

$\mathrm{H}_{\mathrm{a}}: \mathrm{P}>0$ (there is a relationship between the influence of leadership style with work passion).

Where $\mathrm{H}_{\mathrm{o}}$ is the null hypothesis, $\mathrm{H}_{\mathrm{a}}$ is the alternative hypothesis and $\mathrm{P}$ is Proportion. Then the results of the calculation of the hypothesis test $(t)$ are compared with the calculation formula $t$ (table) that is, $d b=n-2$, where $d b$ is the degree of freedom and $n$ is the number of samples. If the results of the calculation of the hypothesis test $(\mathrm{t})$ are smaller than $\mathrm{t}$ table then $\mathrm{H}_{\mathrm{o}}$ is accepted, while $\mathrm{H}_{\mathrm{a}}$ is rejected, which means the two variables do not influence each other. Conversely, if the test is greater than $t$ table then $\mathrm{H}_{\mathrm{o}}$ rejected while $\mathrm{H}_{\mathrm{a}}$ is accepted means one of the variables has a strong influence relationship on the other variables. 


\section{FINDINGS AND DISCUSSION}

Each leader or boss certainly has a leadership style that is different from one another, the leadership style of a boss can encourage or hinder the enthusiasm and motivation of his subordinates' work. Therefore, the interest in this research is to conduct more in-depth research regarding this influence on the Bureau of Financial and State Assets Inventory of the Department of Religion of the Republic of Indonesia. Where the scope of the discussion is only limited to the influence of leadership style on employee passion at the Bureau of Financial and State Assets Inventory of the Department of Religion the Republic of Indonesia which is limited to the period 2003 to 2004.

Data collection was carried out to capture employee responses about the leadership style of superiors and their influence on employee passion by distributing questionnaires to 30 employees.

The questionnaire consisted of questions related to the leadership style and employee passion. In summary, the calculation analysis can be concluded that the correlation analysis above $r=76$, it can be concluded that there is a strong influence relationship between the leadership style of a superior to the passion of subordinate employees at the Financial Bureau and the State Assets Inventory of the Department of Religion of the Republic of Indonesia.

\section{CONCLUSION AND SUGESTION}

From the results of the analysis it appears that the leadership style found in the Bureau of Financial and State Assets Inventory of the Department of Religion of the Republic of Indonesia is more directed towards the democratic leadership style. After seeing the results of the analysis carried out it appears that the employee passion at the Bureau of Financial and State Assets Inventory of the Department of Religion the Republic of Indonesia has a great work passion in carrying out daily tasks / work, so this can increase passion.

Based on the results of the analysis that has been obtained regarding the relationship of leadership style influence on employee passion at the Bureau Financial and State Assets Inventory The Department of Religion the Republic of Indonesia shows the results of the analysis using the correlation coefficient method that $(\mathrm{r}=0.76)$ shows that there is a strong influence relationship between a boss's leadership style on increasing the passion of subordinates or employees. Likewise from the results of the hypothesis test it can be proven that there is a strong influence relationship between the variables of superior leadership style on employee passion or subordinates.

To be able to maintain and further improve employee passion at the Bureau of Financial and State Assets Inventory of the Department of Religion the Republic of Indonesia, so that the chief officials or superiors as far as possible avoid the nature / attitude with the autocratic leadership style in carrying out their duties providing increased welfare in the form of increased allowances, basic salaries and appreciation for employees so that the relationship can be established properly between leaders and subordinates who have been well established.

In order to increase the effectiveness and efficiency of the leadership should continue to maintain good communication with subordinates, so as to create a harmonious relationship between leaders and subordinates which will certainly have a positive impact on improving employee performance. 


\section{REFERENCE}

Burby, Raymond J., Alih Bahasa M. Manullang, Leadership, Yogyakarta : Liberty, 1989

Cribbin, James J., Alih bahasa Rochmulyati Hamzah, Leadership- Strategies for Effective Organizations, Jakarta : PT. Pustaka Binaman Pressindo, 1984

Flippo, Edwin B., Personnel Management, Sixth Edition, Volume 1, Jakarta : Publisher Erlangga, 1984

Handoko, T. Hani, Personnel Management and Human Resources, Edition Second, Yogyakarta : BPFE, 2000

Hasibuan, Malayu, S.P., Human Resource Management, Revised Edition Jakarta : PT Bumi Aksara, 2001

Kusmayadi, Statistics, First Edition, Jakarta : Nusa Gempita, 1988

Mc Kenna, Eugene and Nic Beech. Translation of Totok Budi Santosa, Human Resource Management, Yogyakarta: Andi, 2002

Sarwoto, Fundamentals of organization and management, Fourth Edition, Jakarta : Ghalia Indonesia, 1981

Siagian, Sondang P., Leadership Theory \& Practice, Jakarta : PT Rineka Cipta, 2003

Tyson, Shaun and Tony Jackson. Alih bahasa Deddy jacobus \& Dwi Prabantini, Organizational behavior, Yogyakarta : Andi : 1992 